ORIGINAL ARTICLE

\title{
Satiety Profiles in Obese and Normal Adults After High-Carbohydrate Diet Ingestion
}

\author{
A FAHMY ARIF TSANI ${ }^{1}$, WIDOWATI, S.A ${ }^{2}$, FILLAH FITHRA DIENY ${ }^{1}$, NURMASARI WIDYASTUTI ${ }^{1}$, ANIS SEPTIYANI ${ }^{1}$ \\ ${ }^{1}$ Department of Nutrition Science, Faculty of Medicine, Diponegoro University, Semarang, Central Java, Indonesia \\ ${ }^{2}$ Panti Rini Hospital, Yogyakarta, Indonesia \\ Corresponding author: A Fahmy Arif Tsani, Email: fahmi_tsani@yahoo.com, 085875972785
}

\begin{abstract}
Background : Obesity is one of the nutritional problems with an increase in prevalence every year. To avoid obesity, the selection of foods with the right nutrients is needed. The choice of foods with the right nutrients can affect the span of satiety. Carbohydrate is one of the macronutrients consumed in large quantities every day. Carbohydrate is important components that play a role in insulin secretion and postprandial blood glucose.

Objective : To determine the differences of satiety profiles in obese and normal adults after high-carbohydrate diet ingestion.

Methods : The study design was experimental with a pre-post group. The research subjects were 17 peoples about 20-23 years old were given two isoenergetic high carbohydrate meal tests. Satiety was measured using a Visual Analogue Score (VAS) questionnaire. Nutritional status is determined by BMl indicators. Data were analyzed using independent sample t-test and paired t-test.

Results : The average of fullness in obese subjects (207.81 \pm 63.03$)$, higher than normal subjects (141.97 \pm 37.65$)$. The average of hunger, prospective food consumption (PFC), and desire to eat in obese subjects were $46.31 \pm 28.48 ; 40.08 \pm 20.83 ; 37.39 \pm 26.86$ and the normal subjects were $54.80 \pm 15.92 ; 49.09 \pm 14.17 ; 46.20 \pm 16.56$ respectively. The effect of satiety profile in obese subjects stopped at 150 minutes, faster than the normal subject's which still exist until 180 minutes after ingestion.

Conclusion : There is a significant difference of satiety profiles in obese and normal adults. Normal subjects have satiety effects longer than obese subjects after high-carbohydrate diet ingestion.

Keywords : Carbohydrate; Glycemic Index; Satiety; Nutritional status.
\end{abstract}

\section{INTRODUCTION}

Obesity is one of the nutritional problems with an increase in prevalence every year. The increasing prevalence of obesity is not only in developed countries, but also in developing countries, one of which is Indonesia. The report of National Basic Health Research in Indonesia showed the prevalence of obesity in adult men and women reached $19,7 \%$ and $32,9 \%{ }^{1}$ Obesity in developing countries is caused by changes in lifestyle, social, economic growth, modernization, urbanization, and the globalization of the food market. ${ }^{2}$ Obesity is a risk factor for various diseases such as hypertension, heart failure, coronary artery disease, diabetes mellitus, gallstones, fatty liver, and joint complaints. ${ }^{3}$ Obesity caused by energy imbalance where energy intake is more than what is expended. Excessive food intake is one of the causes of a person being obese. ${ }^{4}$ One of the reasons for excessive intake is the effect of satiety and hunger that is different in each type of food. The selection of foods that are not following the principle of balanced nutrition such as consuming too many foods and sugary drinks, high-fat foods and consuming fewer vegetables and fruit can have an impact on overweight which then develops into obesity. Obesity can be prevented by paying attention to the selection of the right food (nutrition) so that it affects the satiety profiles. Satiety is a period of feeling full after eating until feel hungry again. Satiety profiles consist of four component: appetite, hunger, fullness, dan satiation. ${ }^{5}$ Obese people are encouraged to choose foods with nutrients that can prolong satiety so that they can avoid overeating behaviour and reduce the risk of obesity. Different of food sources with the same number of calories have different satiety effects. Satiety refers to the postprandial state that influences the interval between meals. Postprandial glucose and insulin levels also play roles in the regulation of satiety. ${ }^{6}$

Carbohydrate is one of the macronutrients consumed in large quantities every day. Carbohydrate is important components that play a role in insulin secretion and postprandial blood glucose. The amount of carbohydrates and the type of carbohydrates consumed affects the secretion of insulin and blood glucose. ${ }^{7}$ Changes of insulin secretion and blood glucose are caused by differences the glycemic index in food. The glycemic index (IG) shows the ability of carbohydrate in food to increase blood glucose levels. ${ }^{8}$ Carbohydrate can affect satiety through changes in blood glucose, changes in metabolism in the liver, end products of carbohydrate metabolism, and secretion of hormones that affect satiety such as insulin, GLP-1 and amylin. ${ }^{9} \mathrm{~A}$ study shows that low Gl foods result in a slow and prolonged disposal glucose after a meal and resulting in a greater satiety than high glycemic index and insulin response foods. ${ }^{10}$ In another study also showed that low GI can decrease hunger and increase satiety, whereas high GI can increase hunger and decrease satiety. ${ }^{11}$. This study aims to determine the differences of satiety profiles in obese and normal adults after high-carbohydrate diet ingestion.

\section{MATERIAL AND METHODS}

The study was experimental with pre-post group design. The subjects of this study were university students. Subject was selected by multistage sampling method. At first, the selection of the subjects by cluster random sampling to select the faculty will be taken. Then consecutive sampling method was used to select the subjects that meet the inclusion criteria. The inclusion criteria were students of 
aged 18-25 years with BMl between 18.5-22.9 $\mathrm{kg} / \mathrm{m}^{2}$ (normal) and $>25 \mathrm{~kg} / \mathrm{m}^{2}$ (obese) who are willing to be the subject by filling out informed concern. Exclusion criteria were subjects have a history of chronic or acute diseases, subjects was ill, pregnancy and breastfeeding, and the subject have a special diet or dietary restrictions. The minimum number of subjects was determined by the Federer formula and obtained as many as 17 subjects.

The data used in the study were primary data, there were subject's characteristic data and satiety profiles. Subject's characteristics data including gender, age, weight, height, and body mass index were obtained through interviews using a questionnaire. Satiety profiles were obtained through interviews using the Visual Analogue Scale (VAS) questionnaire. The Visual Analogue Scales (VAS) is used to assess the intensity of satiety, it can generate highly reproducible satiety profiles over repeated presentation of the same meal conditions. ${ }^{12}$ The Visual Analogue Scale (VAS) questionnaire was filled out before being given a test meal and after being given a test meal at minute 0 and every 30 minutes until the 180th minute. There were two types of test meal given, they were high carbohydrate test meal with high $\mathrm{Gl}$ and high carbohydrate test meal with low Gl. The principle applied is isoenergy or food has the same energy even though the type of food used is different. The composition of macronutrients in the test meal consists of $12 \%$ protein, $20 \%$ fat, and $68 \%$ carbohydrate. The test meal fulfils $20 \%$ of the energy needs of each subject, which has been adjusted to the height, weight, and age of the subject. Analysis of the proportion of macronutrients in a test meal using Nutrisurvey software. The test meal was prepared at the Culinary Laboratory. The composition of food ingredients in the test meal was explained in Table 1.

The subject's body weight was measured using a digital scale (GEA) with an accuracy of $0.1 \mathrm{~kg}$. Subjects were asked to wear minimal clothing, not carry heavy items, and take off shoes and socks. The subject's height was measured using microtoise to the nearest $0.1 \mathrm{~cm}$ and the subject was asked to take off his shoes, both shoes and socks. The subject's body weight and height data were used to determine body mass index (BMI) and determine the nutritional needs of each subject. The nutritional needs of the subjects were calculated using the Harris Benedict formula with a correction of moderate activity factors.

Statistical analysis using Statistical Product and Service Solution (SPSS) software. Univariate analysis was conducted to describe the subject's characteristics and satiety profiles. Shapiro-wilk test was used for checking normality of the data. Bivariate was conducted to analyse the difference of satiety profiles on obese and normal subjects using independent sample t-test. Satiety changes over time in each group were analyzed by Paired t-test. This study had received ethical approval from the Medical and Health Research Ethics Committee (MHREC), Faculty of Medicine, Gadjah Mada University No. KE/FK/1262/EC/2016

\section{RESULTS}

Subject's Characteristic: Table 2. shows the subject's characteristic of the study. In the study, the mean of subject age was 21.65 year, mean of weight was $65.84 \mathrm{~kg}$, mean of height was $162.08 \mathrm{~cm}$, and mean of BMI was 24.97 $\mathrm{kg} / \mathrm{m}^{2}$. There were $52.94 \%$ subjects with normal nutritional status and $47.06 \%$ subject with obesity. There were 9 $(52.94 \%)$ men subjects and 8 (47.06\%) women subjects.

Satiety Profiles on Obese and Normal Subjects: Table 3. shows the differences of satiety profiles on obese and normal subjects in this study. The mean of satiety component in test meal with high $\mathrm{Gl}$ on normal subjects were 152.27 (fullness), 61.37 (hunger), 53.83 (desire to eat), and 51.29 (prospective food consumption/ PFC), whereas on obese subjects were 245.71 (fullness), 54.41 (hunger), 49.73 (desire to eat), and 48.86 (PFC). Mean of satiety component in test meal with low Gl on normal subjects were 131.67 (fullness), 48.24 (hunger), 38.57 (desire to eat), and 46.88 (PFC), whereas on obese subjects were 169.92 (fullness), 38.20 (hunger), 25.04 (desire to eat), and 31.30 (PFC). Table 3 . shows that mean of fullness on obese subjects was higher than a normal subject, mean of hunger, desire to eat, and PFC on normal subjects was higher than an obese subject who given test meal with high or low GI. There was a significant difference of fullness on obese and normal subjects who given test meal with a high $\mathrm{Gl}(p=0.03)$, but there was no significant differences of hunger, desire to eat, and PFC on obese and normal subjects who given test meal with a high $\mathrm{Gl}$ $(p>0.05)$. There was no significant difference of fullness, hunger, desire to eat, and PFC on obese and normal subjects who given test meal with low GI $(p>0.05)$.

Figure 1. shows the satiety changes over time in each group. Normal subjects have satiety longer than obese subjects. The four components of satiety in normal subjects showed the effect of satiety until the 180th minute. Satiety on obese subjects began to disappear in the 150th minute. However, in hunger and desire to eat components, the satiety profiles began to disappear in the 120th minute. There are significant differences of satiety changes over time in each group $(p<0.05)$.

Table 1. The composition of food ingredients in the test meal

\begin{tabular}{|l|l|l|l|}
\hline $\begin{array}{l}\text { Food ingredients } \\
\text { with a high Gl }\end{array}$ & Gl value & $\begin{array}{l}\text { Food ingredients } \\
\text { with low Gl }\end{array}$ & Gl value \\
\hline Rice & 83 & Red rice & 43 \\
\hline Beef & - & Beef & - \\
\hline Carrots & 39 & Carrots & 39 \\
\hline Potatoes & 56 & Red beans & 24 \\
\hline Watermelon & 72 & Pear & 38 \\
\hline
\end{tabular}

Tabel 2. Subject's Characteristic

\begin{tabular}{|l|l|l|}
\hline Variables & $\mathbf{n}$ & Mean \pm SD \\
\hline Age $($ year $)$ & 17 & $21.65 \pm 0.79$ \\
\hline Weight $(\mathrm{kg})$ & 17 & $65.84 \pm 13.73$ \\
\hline Height $(\mathrm{cm})$ & 17 & $162.08 \pm 8.63$ \\
\hline BMI $\left(\mathrm{kg} / \mathrm{m}^{2}\right)$ & 17 & $24.97 \pm 4.48$ \\
\hline Men & $9(52.94 \%)$ & \\
\hline Women & $8(47.06 \%)$ & \\
\hline Nutritional status & & \\
\hline Normal & $9(52.94 \%)$ & \\
\hline Obesity & $8(47.06 \%)$ & \\
\hline
\end{tabular}


Table 3. The Difference of Satiety Profiles on Obese and Normal Subjects

\begin{tabular}{|l|l|l|l|l|}
\hline Test Meal & Satiety Component & $\begin{array}{l}\text { Normal Subjects } \\
(\text { Mean } \pm \text { SD) }\end{array}$ & $\begin{array}{l}\text { Obese Subjects } \\
\text { (Mean } \pm \text { SD) }\end{array}$ & $\boldsymbol{p}^{\star}$ \\
\hline High GI & Fullness & $152.27 \pm 38.45$ & $245.71 \pm 77.52$ & 0.01 \\
\hline & Hunger & $61.37 \pm 14.48$ & $54.41 \pm 21.71$ & 0.49 \\
\hline & Desire to eat & $53.83 \pm 14.72$ & $49.73 \pm 19.95$ & 0.66 \\
\hline & PFC & $51.29 \pm 12.94$ & $48.86 \pm 18.20$ & 0.77 \\
\hline Low GI & & & & \\
\hline & Fullness & $131.67 \pm 37.37$ & $169.92 \pm 48.80$ & 0.12 \\
\hline & Hunger & $48.24 \pm 17.86$ & $38.20 \pm 35.36$ & 0.51 \\
\hline & Desire to eat & $38.57 \pm 18.60$ & $25.04 \pm 33.98$ & 0.37 \\
\hline Average & PFC & $46.88 \pm 15.66$ & $31.30 \pm 23.72$ & 0.17 \\
\hline & & & & \\
\hline & Fullness & $141.97 \pm 37.65$ & $207.81 \pm 63.03$ & 0.03 \\
\hline & Hunger & $54.80 \pm 15.92$ & $46.31 \pm 28.48$ & 0.51 \\
\hline
\end{tabular}
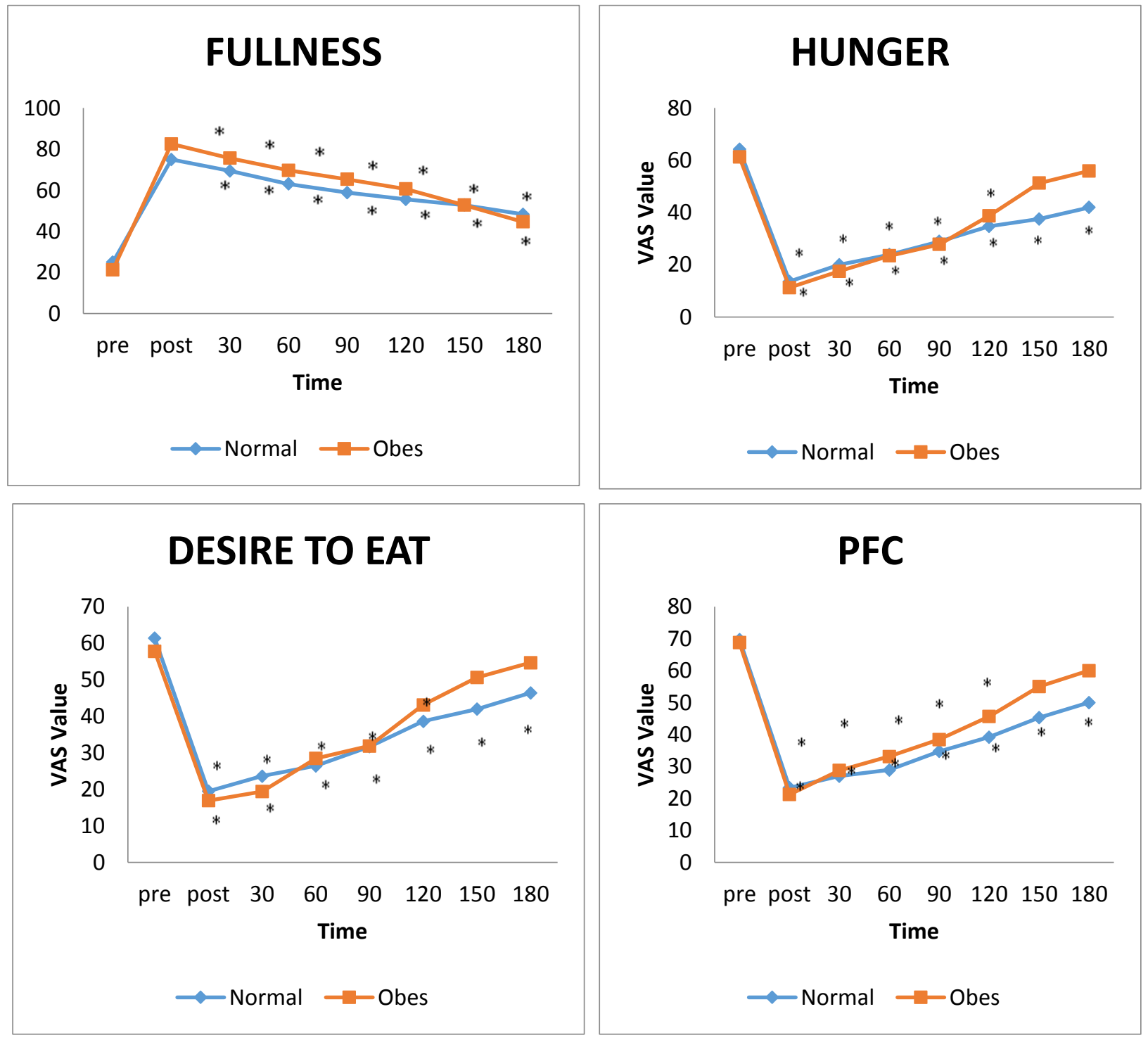

Figure1. Satiety Changes in Obese and Normal Subjects 


\section{DISCUSSION}

A total of subjects were recruited and completed the study. According to inclusion criteria, a total of 17 subjects $(9$ men and 8 women) were thus included in the study. The remaining total of 17 subjects, 8 were obese and 9 were normal. This study to determine the difference of satiety profiles in obese and normal adults after high-carbohydrate diet ingestion. Obesity caused by energy imbalance where energy intake is more than what is expended. Many factors can impact obesity, such as excessive energy intake and nutrient intake from food and beverages, fast food consumption habits, breakfast habits, lack of physical activity, and short duration of sleeping. ${ }^{13-15}$

Table 2. shows that mean of fullness on obese subjects was higher than a normal subject, mean of hunger, desire to eat, and PFC on normal subjects was higher than an obese subject who given high carbohydrate diet with high or low Gl. This result shows that normal subjects have satiety profiles longer than obese subjects. A study state that food with low Gl has a greater effect on reducing appetite. Greater adiposity and weight loss in adults with low $\mathrm{Gl}$ diet have lower hunger rates and greater satiety. ${ }^{16,17}$ The difference of satiety profiles on obese and normal subjects possibility because there is overeat behaviour in people with obese nutritional status. In most obese people, there is no apparent lack of leptin production, because plasma leptin levels increase in proportion to the increase in adipocytes. However, obesity is more related to the presence of leptin resistance, where leptin receptors or post-receptor signalling pathways are usually activated by leptin which may be damaged in obese people. Failure of leptin to prevent an increase in adipocytes in obese people causes an excessive system of eating behaviour regulation. Eating arrangements in the hypothalamus or neurogenic centre in obese people differ from non-obese people. In obese people, there are abnormalities in the mechanism of neurotransmitters or receptors in nerve pathways in the hypothalamus that control food. ${ }^{18}$ If leptin goes down, then fullness goes down. This causes obese people to feel hungry more quickly compared to normal people. Ghrelin is one of indicating hunger signal. Obese and normal peoples are sensitive to appetite stimulation of the ghrelin, but obese peoples are more sensitive to ghrelin so that it will cause overeating. Ghrelin activates the neuropeptides NPY and AgRP to stimulate appetite. Besides ghrelin, motilin is also a potential hormone that stimulates appetite. The acts of this hormone works are similar to ghrelin. Ghrelin and motilin levels will decrease after the intake of food. ${ }^{19}$

Previous research found that obese people have higher energy and basal metabolic energy requirements than thin people. ${ }^{20}$ The most efficient way to get energy is from blood glucose, causing blood glucose levels to decrease and will give the signal to center of hunger in the hypothalamus. Besides, obese people have leptin concentrations per unit body weight lower than normal people. ${ }^{2}$ Low concentration of leptin in the blood causes a higher appetite. This causes obese people more quickly hungry than people with normal nutritional status. ${ }^{21}$ Another study also showed that obese people (men) have energy intake more than people with normal nutritional status whose given high fat diet. ${ }^{22}$ Based on a study, short term feeding with low and moderate index glycemic in a children, obese adolescents and overweight women have shown prolongation of satiety. ${ }^{23}$ However, long term intervention did no show significant differences between low and high glycemic index foods on satiety. ${ }^{6}$ This differences may be due to the effects of other macronutrients in the diet, overall diet quantity, and the effect of the foods on satiety hormone secretion, and energy intake. ${ }^{24}$

The interaction of nutrients with receptors in the gastrointestinal tract has a role in induction satiety by carbohydrates, observation shows that intraduodenal administration glucose can inhibit food intake more than glucose infused intravenously. ${ }^{25}$

\section{CONCLUSION}

There is a significant difference of satiety profiles in obese and normal adults after high-carbohydrate diet ingestion. Normal subjects have satiety effects longer than obese subjects after high-carbohydrate diet ingestion.

Acknowledgements: The authors are grateful to the Development and Application Research Funding and thank all the study subjects for their participation in the study.

\section{REFERENCES}

1. Ministry of Health, Republic of Indonesia. Pokok-Pokok Hasil Riskesdas 2013. Jakarta; 2013.

2. WHO. Obesity and Overweight. 2003.

3. Misnardialy. Obesitas sebagai Faktor Risiko Beberapa Penyakit. Jakarta: Pustaka Obor Populer; 2007.

4. Suyodo A.W, Stiohadi B, Alwi I, Simandibrata K.M, Setati S 2009. Buku Ajar IImu Penyakit Dalam, Jilid III, Edisi V. Jakarta: Pusat Penerbitan Departemen IImu Penyakit Dalam FK UI.

5. Martilla E. Satiety, Weight Management and Foods. Nordic Innovation Centre; 2009.

6. Pan A, Hu FB. Effects of carbohydrates on satiety: differences between liquid and solid food. Curr Opin Clin Nutr Metab Care. 2011 Jul;14(4):385-90.

7. Barclay, et al. Glycemic Index, Glycemic Load, and Chronic Disease Risk - A Metaanalysis of Observational Studies.Am J Clin Nutr. 2008;87:627-37.

8. Association. CD. The Glycemic Index. Canadian Diabetes Association Clinical Practice Guidelines. 2013.

9. Feinle C, O'Donovan D, Horowitz M. Carbohydrate and satiety. Nutr Rev. 2002;60(6):155-69.

10. Brand-Miller JC, Holt SH, Pawlak DB, McMillan J. Glycemic index and obesity. Am J Clin Nutr. 2002; 76(1):281S-5S.

11. Delzenne NM, Cani PD. A place for dietary fibre in the management of the metabolic syndrome. Curr Opin Clin Nutr Metab Care. 2005;8:636-40.

12. Flint, A., Raben, A., Blundell, J.E., and Astrup, A. 2000 Reproducibility, power and validity of visual analogue scales in assessment of appetite sensations in single test meal studies. Int. J. Obes. Relat. Metab. Disord. 24: 38-48. doi:10. 1038/sj.ijo.0.

13. Sudikno SH, Dwiriani CM, Riyadi H. Risk Factors of Central Obesity in Adults Age 25-65 Years in Indonesia (Basic Health Research Data Analysis 2013). Res Nutr Food. 2015;38(2):111-20.

14. Kurdanti W, Suryani I, Syamsiatun NH, Siwi LP, Adityanti MM, Mustikaningsih D, et al. Faktor-faktor yang mempengaruhi kejadian obesitas pada remaja. J Gizi Klin Indones. 2015;11(4):179-90.

15. Theorell-Haglöw, Berne C, Janson C, Sahlin C, Lindberg E. 
Associations between short sleep duration and central obesity in women. Sleep. 2010;33(5):593-8.

16. Ebbeling C., Leidig M., Sinclair K., Hangen J., Ludwig DS. A reduced-glycemic load diet in the treatment of adolescent obesity. Arch Pediatr Adolesc. 2003;157(8):773-9.

17. Hare-Bruun $H$, Flint $A$, Heitmann BL. Glycemic index and glycemic load in relation to changes in body weight, body fat distribution, and body composition in adult Danes1'2'3. Am J Clin Nutr. 2006;84(4):871-9.

18. Guyton, A.C. and Hall, J.E. Textbook of Medical Physiology 11th ed. Philadelphia, PA, USA: Elsevier Saunders. 2006.

19. Hellström PM. Satiety signals and obesity. Curr Opin Gastroenterol. 2013;29(2):222-7.

20. Rimbawan, Albiner S, Hidayat S, Darwin D. Pengaruh Indeks Glikemik, Komposisi, dan Cara Pemberian Pangan terhadap Nafsu Makan pada Subyek Obes dan Normal. Universitas Sumatera Utara; 2010.
21. Dubuc GR, Phinney SD, Stern JS, Havel PJ. Changes of Serum Leptin and Endocrine and Metabolic Parameters After 7 Days of Energy Restriction in Men and Women. Metabolism. 1998;47: 429-434.

22. Speechly DP, Buffenstein R. Appetite Dysfunction in Obese Males: Evidence for a Role of Hyperinsulinaemia in Passive Overconsumption with a High Fat Diet. Europe Journal Clinical Nutrition. 2000; 54: 22533.

23. Poppitt S. Carbohydrates and satiety. University of Auckland; 2013.

24. Niwano $Y$, Adachi T, Kashimura J, Sakata T, Sasaki H, Sekine K, et al. Is glycemic index of food a feasible predictor of appetite, hunger, and satiety? J Nutr Sci Vitaminol. 2009;55:201-7.

25. Feinle C, O'Donovan D, Horowitz M. Carbohydrate and Satiety. Nutr Rev. 2002;60(6):155-69. 